\title{
The effect of intravenous immunoglobulin on the in vitro function of human neutrophils
}

\author{
John W.M. Lawton ${ }^{1}$. J. Paul Robinson ${ }^{2}$ and Gerd O Till ${ }^{2}$ \\ ${ }^{1}$ Deparment of Pathologv, Univer sitv of Hong Kong, Hong Kong, and ${ }^{2}$ Department of Pathologi, Linver wty' of Mhehgan, MI, U:S A
}

(Recelved 27 December 1988, accepted May 2 1989)

\begin{abstract}
Three commercially avalable preparations of human immunoglobulin for intravenous use (IVIgG), namely Gamımune N. Sandoglobulin and Intraglobin F, were tested for their ability to modulate human neutrophil function in vitro IVIgG consistently stimulated the neutrophil respiratory burst at concentrations of 05 to $1 \mathrm{mg} / \mathrm{ml}$, concentrations readily achieved in vivo by moderate-dose therapy Superoxide $\left(\mathrm{O}_{2}{ }^{-}\right)$release was increased by 35-45 nmol per $5 \times 10^{5}$ cells at these concentrations of IVIgG, and $\mathrm{H}_{2} \mathrm{O}_{2}$ production increased in a dose-dependent fashion up to $8 \mathrm{mg} / \mathrm{ml} \mathrm{IVIgG} \mathrm{Luminol-dependent} \mathrm{chemiluminescence} \mathrm{(CL)} \mathrm{was} \mathrm{also} \mathrm{directly}$ stımulated by IVIgG In addition, the effects of both soluble and particulate stımulators ( $N$-formyl-methionyl-leucyl-phenylalanıne, phorbol myristate acetate and opsonized zymosan) on the neutrophil respiratory burst were enhanced by IVIgG In a filter assay of neutrophil migration, using a modified Boyden chamber, no consistent effect on neutrophil locomotion or chemotaxis could be demonstrated The effect of IVIgG on neutrophil metabolısm may contribute to its beneficial therapeutic effect in severe, life-threatenıng infections
\end{abstract}

Key words: Neutrophil, Intravenous immunoglobulın, Superoxıde, Hydrogen peroxıde, Chemılumınescence, Chemotaxıs

\section{Introduction}

The use of intravenous immunoglobulın (IVIgG) is established in the treatment of diopathic thrombocytopenic purpura (ITP), it may be utılized as firstline therapy in children and as second-line therapy

Correspondence Dr John W M Lawton, Reader in Immunology, Department of Pathology, University of Hong Kong, Hong Kong

Abhrevations IVIgG, normal human immunoglobulın for intravenous use, CL, chemılumınescence, ITP, idiopathic thrombocytopenic purpura, AIDS, acquired immunodeficiency syndrome. HBSS, Hank's balanced salt solution, OZ, opsonized zymosan, PMA, phorbol myristate acetate, FMLP, $N$-formyl-Lmethınyl-L-leucyl-L-phenylalanıne, SOD, superoxıde dismutase, DCFH-DA, 2',7'-dichlorofluorescin diacetate. DCFH, 2', $7^{\prime}$ dichlorofluorescin, DCF, 2', $7^{\prime}$-dichlorofluorescein, PBS, phosphate-buffered salıne, cpm. counts per minute, BSA, bovine serum albumin, HSA. human serum albumin, IV, intravenous. IM. intramuscular in adults who are refractory to steroids (Imbach et al , 1981: Newland, 1987). It is also effective in the treatment of allormmune neonatal neutropena (Barundun et al., 1982) and post-transfusion purpura (Mueller-Eckhardt et al., 1983). Regular infusion of IVIgG in primary hypogammaglobulınemıa and related disorders may, in fact, be superior to conventional replacement regimens using intramuscular IgG (McClelland and Yap, 1987). It is of value in the treatment of infants with AIDS (Calvelli and Rubinstein, 1986), however, its place in the treatment of severe infections in the immuno-compromised host has not yet been clearly defined (Yap. 1987)

The mechanism by which IVIgG decreases cell destruction in the immune cytopenias has been a subject of speculation (Imbach, 1983, Salama et al., 1983) Jung1 et al. (1986) demonstrated that IVIgG preparations could interact with $\mathrm{Fc}$ receptors of hu- 
man monocytes and macrophages to inhibit the phagocytosis of IgG-sensitized erythrocytes Highdose IVIgG may also modulate the immune response by reducing the lymphocyte CD4 CD8 ratio and by reducing B-cell immunoglobulın synthesıs (Tsubak1o et al., 1983. Dammacco et al . 1986) Since the neutrophil is central to the acute inflammatory response and in defence against most bacterial pathogens, it is important to know whether neutrophil functions are in any way modulated by IVIgG in the concentrations achieved by high-dose therapy In the present study we set out to examine the effect of three commercially avarlable IVIgG preparations on neutrophil function in vitro, $1 \mathrm{e}$. superoxide ion $\left(\mathrm{O}_{2}{ }^{-}\right)$release. $\mathrm{H}_{2} \mathrm{O}_{2}$ production, chemiluminescence (CL) and chemotaxis

\section{Materials and Methods}

\section{Intravenous tmmunoglobulin}

Three IVIgG preparations were used in this study Intraglobin F (Biotest Pharma Gmbh, Dreieich, F R G , lot 412087), Sandoglobulin (Sandoz Pharmaceuticals Corp., East Haven, NJ, lot 7369.157 0) and Gamımune N (Cutter Biological, Berkeley, CA, lot 40C 13A). Sandoglobulin is prepared by the method developed by the Swiss Red Cross. Cohn effluent III IgG from pooled human plasma is treated at low $\mathrm{pH}$ (4- 4.5) in the presence of a very low concentration of porcine pepsin Gamimune is made by essentially the same method except that pepsin is omitted. In contrast, Intraglobin $F$ is chemically modified. Cohn effluent III IgG is treated with $\beta$-propiolactone These preparations all contaın > 98\% IgG. Gamımune N contains neglıgible amounts of aggregates, dimers and fragments Sandoglobulın contains $<1 \%$ aggregates, 9-10\% dimers and no detectable fragments Intraglobin $\mathrm{F}$ contains no detectable aggregates, $3-4 \%$ dimers and 9-10\% fragments (Lundblad et al . 1987)

Intraglobin $\mathrm{F}$ and Gamımune $\mathrm{N}$ are supplied as solutions of $50 \mathrm{mg}$ protein $/ \mathrm{ml}$. For convenience these were diluted to $40 \mathrm{mg} / \mathrm{ml}$ with Hank's balanced salt solution (HBSS), $\mathrm{pH} 7.4$, so that when further diluted 1:10 under experimental conditions a final concentration of $4 \mathrm{mg} / \mathrm{ml}$ was obtained Sandoglobulin was supplied freeze-dried, and was reconstituted in HBSS at a concentration of $40 \mathrm{mg}$; $\mathrm{ml}$ Doubling dilutions were made in HBSS for dose-response experiments Concentrations of IVIgG used in vitro ranged from $025 \mathrm{mg}$; $\mathrm{ml}$ to 8 $\mathrm{mg} / \mathrm{ml}$. High-dose IVIgG therapy is known to achieve serum concentrations of the order of $8 \mathrm{mg}$ $\mathrm{ml}$ (Pirofsky, 1987)

Each IVIgG contains carrier sugar as at stabilizer and it has been shown previously that both maltose and glucose inhibit the stimulatory effect of IVIgG on neutrophils, measured by $\mathrm{O}_{2}{ }^{-}$release (Koch et al . 1984) Therefore, in all experıments the equivalent concentration of the sugar was added to control tubes which did not contain IVIgG. Intraglobin $\mathrm{F}, 40 \mathrm{mg} / \mathrm{ml}$, contained glucose $18 \mathrm{mg} / \mathrm{ml}$ in excess of glucose in HBSS Sandoglobulin, $40 \mathrm{mg} / \mathrm{ml}$, contaıned sucrose $67 \mathrm{mg} / \mathrm{ml}$. Gamımune $\mathrm{N}, 40 \mathrm{mg} / \mathrm{ml}$, contaned maltose $80 \mathrm{mg} / \mathrm{ml}$ The control sugar concentrations are referred to below as "carrier-sugar'.

\section{pHeffect of II'IgG}

When added to HBSS Intraglobin $F$ at $8 \mathrm{mg}$ and 4 $\mathrm{mg}: \mathrm{ml}$ reduced the $\mathrm{pH}$ by 0.1 and 005 respectively. Sandoglobulin reduced the $\mathrm{pH}$ by 002 and 001 In contrast, Gamımune $\mathrm{N}$ reduced the $\mathrm{pH}$ by 08 at 8 $\mathrm{mg} / \mathrm{ml}$ and by 03 at $4 \mathrm{mg} / \mathrm{ml}$. Because of this effect. the highest final concentration of Gamimune $\mathrm{N}$ used experımentally was $4 \mathrm{mg} / \mathrm{ml}$ A maxımum drop in $\mathrm{pH}$ from 74 to 71 was considered acceptable in the assay systems of PMN function

\section{Cell stmulants}

Partıculate and soluble stımulants of the neutrophıl respiratory burst were employed to determine whether the stimulated response was modified by the presence of IVIgG Opsonized zymosan (OZ) was used as the particulate stımulant. Zymosan (Sigma Chemical Co., St Lours, MO) was bolled in normal salıne for $1 \mathrm{~h}$, washed once in HBSS and resuspended in HBSS at $50 \mathrm{mg} / \mathrm{ml}$ as a stock suspension which was stored at $4^{\circ} \mathrm{C}$ Zymosan stock was opsonized by incubation with an equal volume of fresh normal human serum at $37^{\circ} \mathrm{C}$ for $30 \mathrm{~mm}$ 
After washing twice in $\mathrm{HBSS}$ it was resuspended in HBSS at $10 \mathrm{mg} / \mathrm{ml}$ and stored at $4^{\circ} \mathrm{C}$. OZ was used within one week of preparation Phorbol myristate acetate (PMA, LC Services Corp., Woburn, MA) and $\quad N$-formyl-L-methionyl-L-leucyl-L-phenylalanıne (FMLP, Sigma Chemıcal Co., St. Louıs, MO) were the soluble stımulants employed

\section{Chemoattractant}

Zymosan-activated serum (ZAS) was the standard chemoattractant. Fresh human serum was incubated with washed Zymosan ( $5 \mathrm{mg}$ Zymosan to $1 \mathrm{ml}$ of serum) at $37^{\circ} \mathrm{C}$ for $30 \mathrm{~min}$ The Zymosan was spun down and the serum pipetted off. ZAS was aliquotted and stored at $-70^{\circ} \mathrm{C}$. A $1 / 7$ dilution of ZAS was used in all experiments

Use of cell stmulants in respiratory hurst assays $\mathrm{OZ}$ was added to the cells to a final concentration of $1 \mathrm{mg} \mathrm{OZ}$ per $5 \times 10^{5}$ cells PMA was used at a final concentration of $10 \mathrm{ng} / \mathrm{ml}$ and FMLP at $10^{-6} \mathrm{M}$. In each case stock solution was diluted in HBSS to an appropriate dilution and $0.1 \mathrm{ml}$ of this dilution was added to $09 \mathrm{ml}$ of the cell reaction mixture. The modifying effect of IVIgG on the stımulation of the respiratory burst was also examined by adding 0.1 $\mathrm{ml}$ of the appropriate dilution of IVIgG immediately before the stımulant.

\section{Separation of neutrophils from blood}

Human blood was taken from healthy volunteers and anticoagulated with preservative-free heparin (Elkıns-Sinn Inc, Cherry Hill, NJ) at $10 \mathrm{U} / \mathrm{ml}$ of blood Neutrophils were separated by buoyant density centrifugation over Ficoll/Hypaque according to the method of Ferrante and Thong (1980). Seven $\mathrm{ml}$ of blood were layered over $4 \mathrm{ml}$ of Neutrophil Isolatıon Medium (Los Alamos Diagnostics, Los Alamos, NM) in a $15 \mathrm{ml}$ tube and centrifuged at 400 $\times g$ for $30 \mathrm{~min}$. After discarding the plasma and mononuclear cell/platelet layers, the neutrophil layer was carefully separated using a Pasteur pipette and immediately diluted in HBSS. The neutrophils together with the contamınating erythrocytes were spun down at $500 \times g$ for $5 \mathrm{~min}$, and the erythrocytes were lysed by $20 \mathrm{~s}$ exposure to distilled $\mathrm{H}_{2} \mathrm{O}$, two cycles. Leukocytes were then washed once in HBSS, resuspended in HBSS and kept on ice until tested for respiratory burst actıvity or chemotaxis. The final cell preparation contained $88-99 \%$ neutrophils (mean, $955 \%$ ) and v1ability was greater than $99 \%$ by trypan blue exclusion.

\section{Superoxide release assay}

Release of superoxide ion $\left(\mathrm{O}_{2}{ }^{-}\right)$was measured by the superoxide dismutase (SOD) inhibitable reduction of cytochrome $c$ as described by McCord and Fridovich (1969) The test was performed in $5 \mathrm{ml}$ polypropylene tubes (Sarstedt, Numbrecht, W Germany). Neutrophils were suspended in HBSS to a concentration of $1 \times 10^{6}$ cells $/ \mathrm{ml} ; 0.5 \mathrm{ml}$ of cell suspension was added to each tube together with 1 $\mathrm{mg} / \mathrm{ml}$ of ferricytochrome c (Sigma Type III, Sigma Chemical Co., St. Lours, MO). Control tubes contained $0.023 \mathrm{mg} / \mathrm{ml}$ of SOD (Diagnostic Data, Mountanview, CA). Volumes were adjusted to 1 $\mathrm{ml}$ with HBSS. Tubes were incubated in a shaking water bath for $20 \mathrm{~min}$ at $37^{\circ} \mathrm{C}$ and the reaction was stopped in the tubes without SOD by adding 0.023 $\mathrm{mg}$ of SOD in $100 \mu \mathrm{l}$. The volumes in all tubes were then made up to $1.8 \mathrm{ml}$ with HBSS and the cells were spun down at $1500 \times g$ for $5 \mathrm{~min}$ at $4^{\circ} \mathrm{C}$ Finally, the reduction of cytochrome $c$ was measured by reading the absorbance of the supernatant at $550 \mathrm{~nm}$ in a spectrophotometer, taking the SODcontaining supernatant as the reference. The difference between the - SOD and + SOD tubes was calculated. Using an extinction coefficient of 185 $\mathrm{cm}^{-1} \mathrm{mM}^{-1}$ for cytochrome $c$ (reduced-oxidized) at $550 \mathrm{~nm}$, the difference in absorbance was multuplied by 97 to obtain $\mathrm{nm} \mathrm{O}{ }_{2}^{-} / \mathrm{ml}$ (Margoliash and Frohwirt, 1959). Additıon of IVIgG and stımulants was carried out as described above.

\section{Intracellular $\mathrm{H}_{2} \mathrm{O}_{2}$ production}

The assay used was that originally described by Keston and Brandt (1965) and adapted for flow cytometry by Bass et al. (1983). It depends on the use of the nonfluorescent hydrophobic compound $2^{\prime}, 7^{\prime}$ dichlorofluorescin diacetate (DCFH-DA) which penetrates the cell membrane and is trapped intracellularly by hydrolytic deacetylation to $2^{\prime}, 7^{\prime}$-d1- 
chlorofluorescin (DCFH) This compound is readily oxidized by $\mathrm{H}_{2} \mathrm{O}_{2}$, in the presence of peroxidase, to the fluorescent compound $2^{\prime}, 7^{\prime}$-dichlorofluorescein (DCF). The conversion to DCF can be measured by flow cytometry, thus giving a quantitative assessment of $\mathrm{H}_{2} \mathrm{O}_{2}$ production withın the cells Freshly isolated neutrophils were suspended in PBS containing $01 \%$ gelatin. $\mathrm{pH} 74$, at $55 \times 10^{5}$ cells, ml, DCFH-DA (Molecular Probes. Eugene, OR) was added to give a concentration of $20 \mu \mathrm{M}$ and the cells were incubated at $37^{\circ} \mathrm{C}$ for $15 \mathrm{~min}$ To each 5 $\mathrm{ml}$ polystyrene tube was added $045 \mathrm{ml}$ of the DCFH-DA labelled cell suspension and after addtion of $005 \mathrm{ml}$ of IVIgG and or cell stımulant the tubes were incubated at $37^{\circ} \mathrm{C}$ for $45 \mathrm{~min}$ in a water bath. Three thousand cells were examined in a flow cytometer (EPICS-541. EPICS Division, Coulter Electronics, Hialeah, FL) equipped with an argon laser set at an excitation wavelength of $488 \mathrm{~nm}$ Green fluorescent emission $(510-550 \mathrm{~nm})$ was recorded Fluorescing neutrophils were separated from other contaminating cell types by electronic gatıng Cell fluorescence was expressed as the mean channel number after correction for the gain settıng of the photomultiplier tube Dose responses to IVIgG preparations were done with single samples In experiments to examine the modulating influence of IVIgG on the effect of cell stimulants, samples were run in triplicate

\section{Chemuluminescence assay}

The Lumınol-amplified chemıluminescent response (CL) of neutrophils was assayed essentially as described by Robinson and Penny (1982) Freshly 1solated neutrophils were suspended in HBSS at $2 \times$ $10^{5}$ cells $\mathrm{ml} 05 \mathrm{ml}$ alıquots of the cell suspension were added to glass scintillation vials, followed by $005 \mathrm{ml}$ of a $10^{-3} \mathrm{M}$ stock solution of 5-amıno-2,3dihydro-1,4-phthalazınedıone (Lumınol, Eastman Kodak. Rochester, NY) and HBBS so that the final reaction volume was $1 \mathrm{ml}$ IVIgG and or stımulants were added and the vials were immediately placed in a liquid scintillation counter (Beckman LS 5801 , Beckman Instruments, Fullertom, CA) set for single-photon counting Chemiluminescence was measured at ambient temperature $\left(23^{\circ} \mathrm{C}\right)$. Samples were recycled for up to $1 \mathrm{~h}$ and $\mathrm{CL}$ was recorded as peak counts per minute (cpm). All CL experıments were performed using single samples because of the need to recycle vials at short time intervals to measure the peak CL response

\section{Chemotaxis assay}

This was performed by measuring the distance of cell migration through a $5 \mu \mathrm{m}$-pore-size nitrocellulose filter in a modified Boyden chamber Chemoattractant (ZAS) or HBSS was pipetted into the lower chambers. The filters (Schleicher \& Schuell, Keene, NH) were saturated in HBSS contannng $0.1 \%$ BSA and clamped between the lower and upper chambers Neutrophils suspended in HBSS with $01 \%$ BSA $\left(15 \times 10^{6}\right.$ cells $\left.\mathrm{ml}\right)$ were dispensed into the upper chambers and cell migration was allowed to proceed at $37^{\circ} \mathrm{C}$ for $50 \mathrm{~min}$. after which the filters were stained with haematoxylin The distance of cell migration was measured by the leading-front method of Zigmond and Hirsch (1972) using a standard microscope micrometer A reading was made in five different fields of each filter and the mean distance migrated was calculated in micrometers All assays were run in duplicate. The effect of IVIgG on chemokinesis or ZAS-induced chemotaxis was examıned by adding IVIgG or carrier-sugar to the cell suspension immedrately before dispensing cells into the chambers

\section{Statistical analysis}

The significance of differences between test groups and controls was calculated using the one-talled $r$ test of Student

\section{Results}

Effect of IVIgG on $\mathrm{O}_{2}{ }^{-}$release and $\mathrm{H}_{2} \mathrm{O}_{2}$ generation

The effect of the three IVIgG preparations on $\mathrm{O}_{2}$ release by human neutrophils in vitro was tested over a range of concentrations from $013 \mathrm{mg} / \mathrm{ml}$ to 8 $\mathrm{mg} / \mathrm{ml}$ The results are summarized in Table I Stımulation at levels of statistical significance was seen in the concentration range 1-2 $\mathrm{mg} / \mathrm{ml}$. Sandoglobu- 
lin had the greatest stimulatory effect, and the maximum increment of $4.7 \mathrm{~nm}$ was seen at a dose of 1 $\mathrm{mg} / \mathrm{ml}$. Intraglobin $\mathrm{F}$ was inhibitory at the highest concentration used $(8 \mathrm{mg} / \mathrm{ml})$

To exclude the possibility that this stımulation of $\mathrm{O}_{2}{ }^{-}$release was simply due to protein, human serum albumın (HSA) was added to neutrophils at concentrations of 2 and $4 \mathrm{mg} / \mathrm{ml}$ and $\mathrm{O}_{2}{ }^{-}$release was compared with control cells to which no HSA was added $\mathrm{HSA}$ inhibited $\mathrm{O}_{2}{ }^{-}$release at these concentrations

In contrast to the effect on $\mathrm{O}_{2}{ }^{-}$release. Intraglobin $F$ and Sandoglobulin resulted in increased $\mathrm{H}_{2} \mathrm{O}_{2}$ production by neutrophils in a dose-dependent fashion up to the highest concentration $(8 \mathrm{mg}$ ' $\mathrm{ml}$ ) Peak stimulation by Gamımune $\mathrm{N}$ was seen at $1 \mathrm{mg} / \mathrm{ml}$ (Fig. 1.)

Further experıments were performed to determine whether IVIgG had any enhancing or additıve effect on stimulated $\mathrm{O}_{2}{ }^{-}$release and $\mathrm{H}_{2} \mathrm{O}_{2}$ production when OZ, PMA and FMLP were used a stimulants. The stimulants were added to the cells $1 \mathrm{~m}$ mediately after the IVIgG (or control sugar solution). The results of these experiments are summarized in Table II Sandoglobulin enhanced $\mathrm{O}_{2}{ }^{-}$ release in the presence of all three stımulants, whereas Gamımune N enhanced only FMLP stım-

\section{TABLE I}

Effect of IVIgG on $\mathrm{O}_{2}{ }^{-}$release from human neutrophıls

\begin{tabular}{lccc}
\hline $\begin{array}{l}\text { IVIgG } \\
(\mathrm{mg} ; \mathrm{ml})\end{array}$ & $\mathrm{JO}_{2}{ }^{-}$release $(\mathrm{nmol})^{\mathrm{a}}$ & \\
\cline { 2 - 4 } & Intraglobin F & Sandoglobulin & Gamimune N \\
\hline 013 & 113 & $\mathrm{NT}$ & 044 \\
025 & 049 & 245 & 225 \\
05 & 146 & 314 & 230 \\
1 & $167^{\mathrm{c}}$ & $470^{\mathrm{c}}$ & $206^{\mathrm{c}}$ \\
2 & $255^{\mathrm{c}}$ & $358^{\mathrm{c}}$ & 343 \\
4 & 103 & $353^{\mathrm{c}}$ & 279 \\
8 & -216 & $431^{\mathrm{c}}$ & $\mathrm{NT}^{\mathrm{b}}$
\end{tabular}

${ }^{4} \mathrm{AO}_{2}{ }^{-}$release is the increase $1 \mathrm{O} \mathrm{O}_{2}{ }^{-}$release in nanomoles per 5 $\times 10^{5}$ cells above controls containing carrier-sugar in place of IVIgG

b NT, not tested

? $p<005$

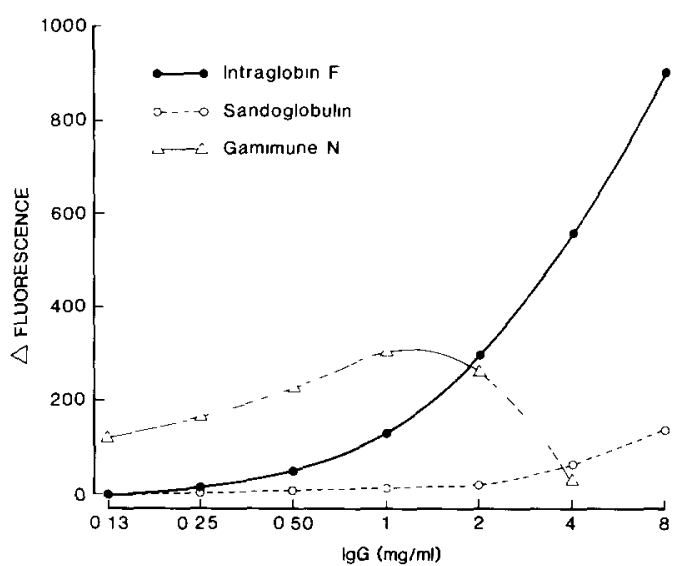

Fig 1 Effect of IVIgG on $\mathrm{H}_{2} \mathrm{O}_{2}$ production The increase in intracellular $\mathrm{H}_{2} \mathrm{O}_{2}$ is measured by the net increase in green fluorescence (1fluorescence) expressed as the increase in mean channel number above controls The maximum channel number. after correction for gain settıng, was 2560 The assay was modıfied from Bass et al (1983) In this dose-response expertment, because of strict time limitations in performing the assdy on freshly prepared cells, single samples were assayed

ulation and Intraglobin signtficantly decreased PMA stımulation.

All three IVIgG preparations enhanced the stimulatory effects on $\mathrm{H}_{2} \mathrm{O}_{2}$ production, with the single exception that Gamımune $\mathrm{N}$ had no additional effect in the presence of PMA.

\section{Effect of IVIgG on neutrophll chemuluminescence}

Both Intraglobin $\mathrm{F}$ and Gamimune $\mathrm{N}$ stimulated Luminol-amplified chemiluminescence at concentrations in the region of $0.5-1 \mathrm{mg} / \mathrm{ml}$ Stimulation indices $(\mathrm{SI}=$ peak stimulated $\mathrm{cpm} \cdot$ peak control cpm) were in the range 1.5 to 23 . Sandoglobulın, on the other hand, stımulated only at the highest dose ( $8 \mathrm{mg} / \mathrm{ml})$, SI 27.

Assays were carried out to determine the effect of the presence of IVIgG on CL stimulated by OZ particles. IVIgG (or control sugar solution) was added to the cells immediately before the OZ. Intraglobin had no additive effect and was inhibitory at 4 and 8 $\mathrm{mg} / \mathrm{ml}$ Sandoglobulin and Gamimune $\mathrm{N}$ both showed a dose-dependent enhancing effect, maximal at $1 \mathrm{mg} / \mathrm{ml}$. The results using Gamimune $\mathrm{N}$ are 
TABLE II

Effect of IVIgG on stımulated $\mathrm{O}_{2}{ }^{-}$release and $\mathrm{H}_{2} \mathrm{O}_{2}$ production by human neutrophils

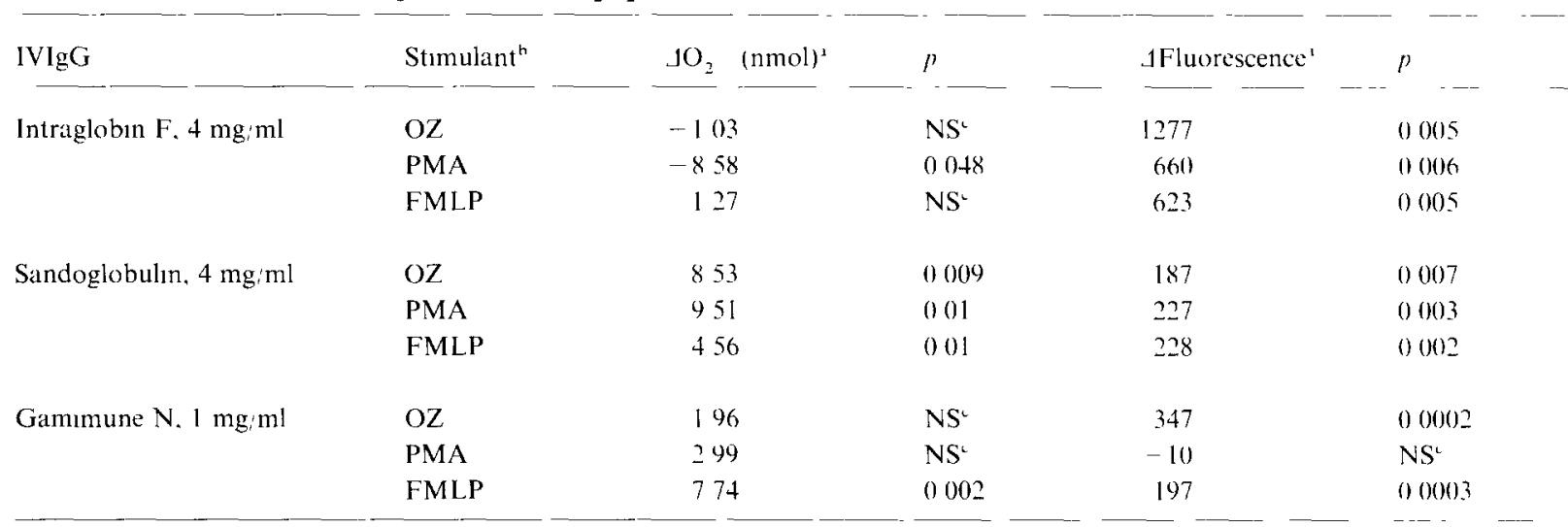

${ }_{4} \mathrm{HO}_{2}{ }^{-}$is the increase in $\mathrm{O}_{2}{ }^{-}$reledse in nanomoles per $5 \times 10^{5}$ cells. AFluorescence is the net increase in green fluorescence expressed as the increase in mean channel number above controls contanıng approprate carrier-sugar in place of IVIgG

b OZ, 1 mgiml, PMA, 10 ng/ml, FMLP, $10^{-6} \mathrm{M}$

NS $=$ not signiticant, $p>005$

shown in Table III, and the effect of Sandoglobulın is shown in Fig. 2

\section{Effect of IVIgG on neutrophll locomotion and chemo- taxts}

In this part of the study only three concentrations of IVIgG were utilized $0.25,1$ and $4 \mathrm{mg} / \mathrm{ml}$ When the lower chamber contained only HBSS, migration

\section{TABLE III}

Enhancing effect of Gamımune $\mathrm{N}$ on neutrophil chemilumınescence response to $\mathrm{OZ} 02 \mathrm{mg} / \mathrm{ml}$

\begin{tabular}{lcc}
$\begin{array}{l}\text { Gamimune } N \\
(\mathrm{mg} / \mathrm{ml})\end{array}$ & $\begin{array}{l}1 \mathrm{CL}^{\mathrm{a}} \\
\left(\mathrm{cpm} \times 10^{-6}\right)\end{array}$ & $\begin{array}{l}\text { Stımulation } \\
\text { Index }^{\mathrm{b}}\end{array}$ \\
\hline 025 & 204 & 171 \\
05 & 367 & 252 \\
1 & 365 & 281 \\
2 & 272 & 216 \\
4 & 495 & 122 \\
8 & $-144^{\mathrm{c}}$ & 047
\end{tabular}

- $J \mathrm{CL}$, increase in peak chemiluminescence response above controls containing carrier-maltose in place of IVIgG

b Stimulation index, ratio of peak $\mathrm{CL}$ responses with and without IVIgG

c Depressed response probably accounted for by fall in $\mathrm{pH}$ at highest concentrations of Gamimune $\mathrm{N}$ of cells through the filter was significantly increased only by Intraglobin $0.25 \mathrm{mg} / \mathrm{ml}$ and Gamımune N I $\mathrm{mg} / \mathrm{ml}$ ZAS-ınduced directed migration of neutro-

\section{TABLE IV}

Effect of IVIgG on neutrophil locomotion and ZAS-ınduced $d_{1}$. rected migration

\begin{tabular}{|c|c|c|c|}
\hline & \multirow{2}{*}{$\begin{array}{l}\text { IVIgG } \\
(\mathrm{mg} / \mathrm{ml})\end{array}$} & \multicolumn{2}{|c|}{ JCell migration $(\mu \mathrm{m})^{d}$} \\
\hline & & $\begin{array}{l}\text { HBSS } \\
\text { lower chamber }\end{array}$ & $\begin{array}{l}\text { ZAS in } \\
\text { lower chamber }\end{array}$ \\
\hline Intraglobulın & $\begin{array}{l}025 \\
1 \\
4\end{array}$ & $\begin{array}{l}124^{b} \\
122 \\
38\end{array}$ & $\begin{array}{r}61 \\
-\quad 94 \\
-199\end{array}$ \\
\hline Sandoglobulin & $\begin{array}{l}025 \\
1 \\
+\end{array}$ & $\begin{array}{r}-13 \\
-103 \\
63\end{array}$ & $\begin{array}{l}-122 \\
-1341 \\
-13\end{array}$ \\
\hline Gamimune & $\begin{array}{l}025 \\
1 \\
4\end{array}$ & $\begin{array}{c}75 \\
248^{b} \\
275\end{array}$ & $\begin{array}{l}179 \\
464 \\
132\end{array}$ \\
\hline
\end{tabular}

" JCell migration, incredse in distance travelled compared to control cells with carrier-sugar in place of IVIgG (A negative value indicates an actual decrease in distance travelled compared to control cells )

म $p<005$

- Cells migrated through filters Figure is increase in mean cells per HPF 


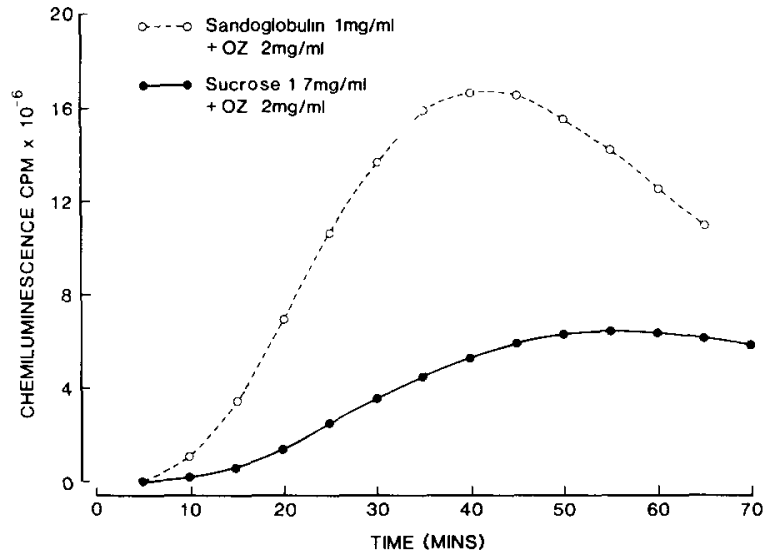

Fig 2 Enhancing effect of Sandoglobuln $02 \mathrm{mg} / \mathrm{ml}$ on neutrophil chemiluminescence response to opsonized zymosan Controls contained sucrose $17 \mathrm{mg} / \mathrm{ml}$ in place of IVIgG In order to recycle vials as rapıdly as possible in the counter, single samples were assayed

phils was decreased by most concentrations of Intraglobin and Sandoglobulın, and in the presence of Gamimune $\mathrm{N}$ migration was increased, these differences did not reach levels of statistical significance (Table IV).

\section{Discussion}

Varıous mechanisms have been proposed to explain how IVIgG reduces cell destruction in the immune cytopenias (Imbach, 1983). The most popular theory is that IVIgG interacts with Fc receptors of mononuclear phagocytes, thereby inhibiting the phagocytosis of cells (red cells, platelets or neutrophils) opsonzed by autoantibody (or alloantibody). There is in vitro experimental evidence to support this concept (Jungi et al., 1986). An equally attractive hypothesis is that infused immunoglobulin binds to red blood cells which are then preferentially sequestered by macrophages; support for this mechanism is provided by the clinical finding that the injection of anti-Rho(D) is effective in treating ITP (Salama et al.. 1983, Baglın et al., 1986). In addition to the effect of macrophage blockade, IVIgG may modulate the immune response by altering the proportions of $\mathrm{T}$-cell subsets or by non- specific inhıbıtion of B-cell responsıveness (Tsubiakıo et al., 1983; Dammacco et al., 1986; Stohl, 1986).

The beneficial effect of IgG replacement therapy in hypogammaglobulinemı is presumably due largely to passive immunization with preformed specific antibodies; such antıbodies against a wide range of bacterial and viral pathogens can readily be demonstrated in human IgG for both IV and IM use (Yap, 1987). However, experımental and clinical evidence indicates that IVIgG may interact with macrophage $\mathrm{Fc}$ receptors and, in other unspecified ways, modulate the immune response, as already discussed This raises the possibility that it may also influence neutrophil function. Koch et al. (1984) showed that IVIgG can stimulate neutrophil $\mathrm{O}_{2}{ }^{-}$ release and chemiluminescence in vitro; the present study was designed to further investigate this effect. The neutrophil respiratory burst was examined using three assays; $\mathrm{O}_{2}{ }^{-}$release, $\mathrm{H}_{2} \mathrm{O}_{2}$ production and Luminol-dependent chemiluminescence (CL). The $C L$ response of activated neutrophils correlates well with metabolic activation (Allen et al, 1972), but there has been considerable controversy as to what is the chief oxidizing species measured in Lumınoldependent CL. De Chatelet and Shirley (1981) have argued that it is largely due to $\mathrm{HOCl}$ which diffuses extracellularly and reacts with Luminol to form amınophthalate ions and light generation.

In all three types of assay our results indicated that IVIgG can directly stimulate the neutrophil respiratory burst. The maximum increase in $\mathrm{O}_{2}{ }^{-}$release was of the order of 3.5-4.55 nmol (per $5 \times 10^{5}$ cells) and this was achieved by concentrations of $0.5-1 \mathrm{mg} / \mathrm{ml}$ IVIgG, concentrations which are readily achieved in moderate-dose IVIgG therapy. High-dose therapy can achieve serum concentrations of the order of $8 \mathrm{mg} / \mathrm{ml}$ (Pirofsky, 1987). In the case of $\mathrm{H}_{2} \mathrm{O}_{2}$ production, the stımulatory effect on $\mathrm{H}_{2} \mathrm{O}_{2}$ was more clearly dose-dependent, and for two IVIgG preparations it appeared that the maximal $\mathrm{H}_{2} \mathrm{O}_{2}$ response was not reached in the range of concentrations used. The stimulatory effects of $\mathrm{OZ}$, PMA and FMLP were enhanced by IVIgG and this enhancing effect was more clearly seen in the $\mathrm{H}_{2} \mathrm{O}_{2}$ assay. 
CL responses also indicated that IVIgG can directly stımulate neutrophils, as well as being able to enhance the metabolic response following ingestion of $\mathrm{OZ}$.

There are few published reports on the effects of IVIgG on neutrophils, either in vivo or in vitro. Koch et al (1984), using a blood leukocyte preparation consisting of both neutrophils and mononuclear cells, demonstrated that the neutrophil respiratory burst was stimulated in vitro by IVIgG. The maximal increases $1 \mathrm{n} \mathrm{O}_{2}{ }^{-}$release, $5 \mathrm{nmol}$ per $10^{6}$ cells, was quite consistent with our own findings. Redd et al (1988) reported that human IVIgG reduced the severity of neutropenta in newborn rats after intrapulmonic injection of group B streptococcr This was thought to be due to increased release of neutrophils from the marrow and egress from the blood into infected tissue IVIgG did not affect the production of neutrophils in vitro or in vivo

Of the three IVIgG preparations used in the present study, Intraglobin F (Biotest) has the highest content of dimers and aggregates (Lundblad et al . 1987). If the observed stimulation of neutrophils was initiated by the interaction of aggregated IgG with $\mathrm{Fc}$ receptors, we would have expected Intraglobın F to give consistently higher levels of stımulation This was not observed Monomeric IgG is known to attach to $\mathrm{Fc}$ receptors of human monocytes (Kurlander, 1980) and, in the same way, must be able to bind to $\mathrm{Fc}$ receptors of neutrophils. The stımulatıng effect of IVIgG on neutroph1 metabolism could not be reproduced by another serum protein (HSA), suggesting that Fc receptor-monomenc IgG interaction may be the initiating event

There is no doubt that the benefit of IVIgG therapy in hypogammaglobulınemıa, and in severe infection in the immunocompromised host, is primarily due to the passive provision of preformed antibodies. However, the findings of this study suggest that host defence may benefit secondarily from the direct stimulation of neutrophil metabolism by IVIgG

\section{Acknowledgements}

We are grateful to Prof James Pennington. Cutter Laboratories, Berkeley, Calıfornia, for the gift of Gamımune N and to Dr Volker Lenhard of Biotest Pharma Gmbh. Dreierch, F.R G , for the supply of Intraglobin $\mathrm{F}$ We wish to thank Miss Yvette Chow for her contribution in typing the manuscript

\section{References}

Allen RC, Sjernholm RL. Steele RH Evidence tor the generation of an electronce excitation state(s) in human polymotphonucledr leukocytes and its participation in hactericadal activity Blochem Biophys Res Commun 1972.47 679

Baglin JP. Smith MP, Boughton BJ Rapid and complete response of immune thrombocy topenic put purd to a single injection of rhesus ant1-D immunoglobulın Lancet 1986.1 1329

Bass DA. Paree JW, De Chatelet LR, Szejda P Seed MC Thomas $M$ Flow cytometric studies of oxidative product formation by neutrophils a graded response to membrane stımula tion J Immunol 1983,130 1910

Calvelh TA. Rubinstem A Intravenous gammaglobulin in 1 lants with AIDS Pediatr Infect D1s 1986,5 S207

Dammacco F, Iodice G, Campohasso N Treatment of adult patients with idiopathic thrombocytopenic purputa with intratenous immunoglobulin effects on circulating $T$ cell subsets and PWM-induced antibody synthess in vitro Br I Hacmatol 1986.62125

De Chatelet LR, Shrrley PS Evaluation of CGD by a chemıluminescence assay of microlitre quantites of whole blood Clin Chem 1981,27 1739

Ferrante A, Thong Y'H Optımal conditions for simultaneous purification of mononuclear and polymorphonuclear leucecytes from human blood by the Hypaque-Fuoll method I Immunol Methods 1980,36109

Imbach P. Jung 1 TW Possible mechanism of intravenous immunoglobulin treatment in childhood idiopathe thrombocytopenic purpura (ITP) Blut 1983,46 117

Imbach P, Barundun S, Baumgartner C, Hirt F. Hoter F, Wagner HP High-dose intravenous gammaglobulin theraps of refractor in particular idiopathic thromboxylopenid in child hood Hely Paediat Acld 1981.4681

Jung1 TW. Eiholzer J. Lerch PG. Barundun S The capacity of various types of immunoglobuhn for intravenous use to interact with $\mathrm{Fe}$ receptors of human monocytes and mactophages Blut 1986,53 321

Keston AS Brandt R The fluorometrie analysis of ultramuro quantities of hydiogen peroside Anal Biochem 1965.11 I

Koch C. Valerius NK, Anderson V Intetaction of human IgG preparations with polymorphonuclear leukocytes in vitro $\mathrm{Ac}$ la Path Microbiol Immunol Scand 1984 Sect C 92161 
Kurlander RJ Reversible and irreversible loss of Fc receptor function of human monocytes as a consequence of interaction with immunoglobuln $G$ J Clin Invest 1980,66 773

Lundblad JL, Londeree M, Mitra G Characterisation of various intraglobulin preparations J Infection 1987,153

Margoliash E, Frohwirt N Spectrum of horse-heart cytochrome c Biochem J 1959,71 570

McClelland DBL, Yap PL Clinical use of immunoglobulins Clınıcs Haemat 1987,13 39

McCord JM, Fridovich I Superoxide dismutase An enzymatic function for erythrocuprein (hemocuprein) J B1ol Chem 1969,2446049

Mueller-Eckhardt C, Kuenzlen E, Thilo-Korner D. Pralle H High-dose intravenous immunoglobulin for post-transfusion purpura N Engl J Med 1983,308 287

Newland AC Idiopathic thrombocytopenic purpura and IgG a review J Infect 1987, 15 (Suppl 1) 41

Pirofsky B Clinical use of a new pH 425 intravenous immunoglobulın preparation (gamımune-N) J Infect 1987,1529

Pollack S, Cunningham-Rundles C, Smithwick EM, Barundun S, Good RA High dose intravenous gammaglobulın for autoimmune neutropenla N Engl J Med 1982,307 253

Redd H, Christensen RD, Fischer GW Circulating and storage of neutrophils in septic neonatal rats treated with immune globulin J Infect Dis 1988,157 705

Robinson JP, Penny R Chemiluminescence response in normal human phagocytes I Automated measurements using a standard liquid scintillation counter $\mathbf{J}$ Clin Lab Immunol 1982.7215

Salama A, Mueller-Eckhardt C, Kafel V Effect of intravenous immunoglobulin in immune thrombocytopenia Lancet 1983,11193

Stohl W Cellular mechanisms in the in vitro inhibition of pokeweed mitogen-induced B cell differentiation by immunoglobulin for intravenous use J Immunol 1986, 1364407

Tsubakı T, Kurata Y, Katagırı S, Kanakura Y, Tamak1 T, Kuyama J, Kanayama Y, Yonezawa T, Tarvı S Alteratıon of $T$ cell subsets and immunoglobulin synthesis in vitro during high-dose $\gamma$-globulın therapy in patients with idiopathic thrombocytopenic purpura Clin Exp Immunol 1983,53 697

Yap PL The use of intravenous immunoglobulın for the treatment of infection an overview J Infect 1987,15(Suppl 1) 21

Zigmond SH, Hirsch JG Effects of cytochalasin B on polymorphonuclear leucocyte locomotion, phagocytosis and glycolysis Exp Cell Res 1972,73383 